ScIDice

\section{Green Synthesis Of Reduced Graphene Oxide Nanoparticles, Its Characterization and Antimicrobial Properties against Common Oral Pathogens}

Research Article

Iffat Nasim $^{1 *}$, S. Rajeshkumar ${ }^{2}$, V Vishnupriya ${ }^{3}$

${ }^{1}$ Professor and Head, Department of Conservative Dentistry and Endodontics, Saveetha Dental College and Hospitals, Saveetha Institute of Medical and technical Sciences, Saveetha University, Chennai, India.

${ }^{2}$ Associate Professor, Department of Pharmacology, Saveetha Dental College and Hospitals, Saveetha Institute of Medical and technical Sciences, Saveetha University, Chennai, India.

${ }^{3}$ Professor, Department of Biochemistry, Saveetha Dental College and Hospitals, Saveetha Institute of Medical and technical Sciences, Saveetha University, Chennai, India.

\title{
Abstract
}

The graphene and its based materials are widely used in biomedical applications especially in oseointegration and implants preparation. We synthesized the reduced graphene oxide nanoparticles by green synthesis method. The plant extract of $A n$ drographis paniculata and Ocimum sanctum Linn were used as reducing agent. UV-vis spectroscopy, FT-IR, XRD, TEM analysis were used for characterization of the resulting nanoparticles. The antimicrobial activity of the nanoparticles was also assessed against common oral pathogens. Brine Shrimp Lethality assay was utilized to check the cytotoxicity of newly synthesized nanoparticles. The nanoparticles were successfully synthesized and showed good antimicrobial activity with minimum cytotoxic effects.

Keywords: Antimicrobial Activity; Graphene Oxide; Green Synthesis; Nanoparticles; Oral Pathogens.

\section{Introduction}

Graphene is a carbon based flat monolayer arranged in a two dimensional hexagonal structure. It was first prepared by Geim and Novoselov in 2004. In 2008 it was introduced for the first time in the field of biomedical sciences [1]. It has distinguished mechanical, electrochemical and physical properties. The graphene family nanomaterials has several graphene derivatives, such as Few-Layered Graphene (FLG), ultrathin graphite, Graphene Oxide (GO), reduced Graphene Oxide (rGO) and graphene nanosheets [2].

It has a remarkable antibacterial ability against both Gram-negative and Gram-positive bacteria as studied by various researchers $[3,4]$. Antibiotic resistance and prevalence of biofilms are major threats which evokes the development of new antimicrobials. Owing to the exciting properties of nanoparticles, they have been used in biomedical field for various applications. They are small in size, large surface area and ability to interact with cells which helps in promoting their adhesion, migration, proliferation and differentiation [5].

There are conventional chemical and physical methods which are used as reducing agents for nanoparticle synthesis but they possess environmental and biological risks during the synthesis procedures. To achieve environmentally friendly approach nanoparticles are synthesized by biological or green-chemistry synthesis. In the literature, various green synthetic approaches to synthesize silver nanoparticles using micro- organisms such as bacteria [6], yeast [7] and fungi [8] have been reported. But, there are several drawbacks, which includes multiple purification steps and the elaborate process of maintaining the microbial culture.

Using plant extracts as reducing and stabilizing agents for the synthesis of nanoparticles is considered to be an eco-friendly and rapid strategy. It can significantly make the nanoparticles more biocompatible and non-toxic $[9,10]$. In the present study we syn-

*Corresponding Author:

Iffat Nasim,

Professor and Head, Department of Conservative Dentistry and Endodontics, Saveetha Dental College and Hospitals, Saveetha Institute of Medical and technical Sciences, Saveetha

University, Chennai, India.

Tel: +919940063567

E-mail: iffatnasim@saveetha.com

Received: January 25, 2021

Accepted: February 14, 2021

Published: February 22, 2021

Citation: Iffat Nasim, S. Rajeshkumar, V Vishnupriya. Green Synthesis Of Reduced Graphene Oxide Nanoparticles, Its Characterization and Antimicrobial Properties against Common Oral Pathogens. Int J Dentistry Oral Sci. 2021;8(2):1670-1675. doi: http://dx.doi.org/10.19070/2377-8075-21000332

Copyright: Iffat Nasim ${ }^{\circ} 2021$. This is an open-access article distributed under the terms of the Creative Commons Attribution License, which permits unrestricted use, distribution and reproduction in any medium, provided the original author and source are credited. 
thesized graphene oxide nano-particles by green synthesis using the leaf extract of Andrographis paniculata and Ocimum sanctum Linn.

The leaves of A. paniculata are widely used in Indian folk-medicine for treatment of different illness, especially as an anti-diabetic drug. The entire plant is used as medicine. According to Ayurveda, this plant is bitter, acrid, cooling, laxative, vulnerary, antipyretic, anti-inflammatory, expectorant, cures hyperdipsia, burning sensation, wounds, ulcers, malaria, diarrhoea etc. It also has been proven to be a hepato-protective drug [11, 12].

Ocimum sanctum Linn. commonly known as'Tulsi has been studied on a major scale and has shown a plethora of pharmacological and biological activities benefiting humans since ages. Hence the aim of the present study was to synthesise, characterise graphene oxide nanoparticles using herbal extracts and to check their cytotoxicity and antimicrobial activity against common oral pathogens. We have numerous highly cited publications on well designed clinical trials and lab studies [13-28]. This has provided the right platforms for us to pursue the current study. Our aim was to synthesise, characterise graphene oxide nanoparticles using herbal extracts and to check their cytotoxicity and antimicrobial activity against common oral pathogens.

\section{Materials and Methods}

Andrographis paniculata and Ocimum sanctum Linn leaves were collected freshly and dried in shade for three days. After that they were powdered coarsely.

$0.5 \mathrm{~g}$ of A. paniculata and $0.5 \mathrm{~g}$ of $\mathrm{O}$. sanctum Linn leaves powder was weighed and dissolved in $100 \mathrm{~mL}$ of distilled water and mixed well. After that it was boiled for 5 minutes at 60-800 Cusing a heating mantle. The boiled extract was filtered through Whatman No.1 filter paper, and the supernatant was used.

\section{Synthesis of GONP}

0.6g of graphite nano powder (Sisco Research Laboratories, Maharashtra, India.) and $0.2 \mathrm{~g}$ of sodium hydroxide (MERCK, Mumbai, India.)was dissolved in $50 \mathrm{ml}$ of distilled water, to this $50 \mathrm{~mL}$ of plant extract was added and mixed well. Then the solution was kept in an orbital shaker and magnetic stirrer with hot plate for further mixing. The color change was noted and the nanoparticles formation was monitored. Then this solution was centrifuged at $8000 \mathrm{rpm}$ for 10 minutes. The solution was then filtered using Whatman No.1 filter paper. The prepared solution was then stored in the refrigerator for further use. (Figure 1)

\section{Characterization of GO nanoparticles}

$\boldsymbol{U V}$-vis spectrophotometer Analysis: The reduction of the Graphene oxide ions in solution was monitored by periodic sampling of the solution and subjecting the solution to spectrophotometer. (UV-1800 series).

Transmission electron microscopy: Transmission electron microscopy was done to confirm the size and shape of newly synthesised graphene oxide nanoparticles.
FTIR Analysis and X-ray Diffraction assay: The chemical functional groups of graphene oxide were analysed by FTIR Analysis using Fourier transform infrared spectrometer (PerkinElmer, USA) and X-ray Diffraction assay was performed using X-ray Diffractometer (Bruker, Germany) to observe any crystal structure changes after graphite has been transformed to reduced Graphene Oxide.

\section{Antimicrobial activity test}

$100 \mathrm{~mL}$ of Muller-Hinton agar was prepared, sterilized and poured onto the petriplates. The plates were allowed for solidification. After solidification plates was swabbed with four different oral pathogens namely Streptococcus mutans, Staphylococcus aureus, Pseudomonas sp, Enterococcus faecalis. All microorganisms were maintained at $4^{\circ} \mathrm{C}$ and were isolated from the patients. After swabbing on each plate four wells were formed using a $\mathrm{T}$ shaped well cutter. In the first three wells the test suspension was loaded in the concentration of $25 \mu \mathrm{l}, 50 \mu \mathrm{l}, 150 \mu \mathrm{l}$ respectively. In the fourth well a standard antibiotic in the concentration of $30 \mu \mathrm{l}$ was loaded and the plates were incubated at $37^{\circ} \mathrm{C}$ for $24 \mathrm{hrs}$ and zone of inhibition was measured after incubation.

For Candida albicans , 20ml of Rose Bengal was prepared, sterilised and poured on to a petri plate and allowed for solidification. After solidification plates was swabbed with Candida albicans. After swabbing on each plate four wells were formed using a $\mathrm{T}$ shaped well cutter. In the first three wells the test suspension was loaded in the concentration of $25 \mu \mathrm{l}, 50 \mu \mathrm{l}, 150 \mu \mathrm{l}$ respectively. In the fourth well a standard antibiotic in the concentration of $30 \mu \mathrm{l}$ was loaded. The plates were incubated at $37^{\circ} \mathrm{C}$ for $48 \mathrm{hrs}$ and zone of inhibition was measured after incubation.

The microbiological procedure was repeated three times for each microorganism.

\section{Assessment of Cytotoxicity (Brine shrimp lethality assay)}

The artemia tank was filled with $6 \mathrm{~L}$ of distilled water, to that 50 $\mathrm{g}$ of iodine free salt was added and mixed well using a spatula. 2 capsules containing $15 \mathrm{~g}$ of brine shrimp eggs were added to the tank and left undisturbed for 5 mins for proper soaking in salt water.After that airline tip was placed inside the artemia tank and the aeration level was increased to maximum level according to the manufacturers' instructions.After 24 hrs of incubation, the naupliis were hatched out from the brine shrimp eggs and observed using a stereomicroscope. Five tubes were taken and filled with $3 \mathrm{ml}$ of artificial sea water. 10 naupliis were added in each test tube respectively.Test solution was loaded in the concentration range of $10 \mu \mathrm{l}, 20 \mu \mathrm{l}, 30 \mu \mathrm{l}, 40 \mu \mathrm{l}, 50 \mu \mathrm{l}$. A control tube was prepared by adding $3 \mathrm{ml}$ of artificial sea water, 10 naupliis. The tubes were kept for 24 hrs incubation. After incubation, the live and dead naupliis were counted and lethality was assessed.

\section{Results and Discussion}

\section{UV Spectrophotometer Analysis}

The peak of $285 \mathrm{~nm}$ was observed after $72 \mathrm{hrs}$ which confirmed the synthesis of graphene oxide nanoparticles. (Figure 2) 


\section{Transmission electron microscopy}

The results clearly showed some small spherical and rod shaped nanoparticles in the prepared film. The rod shaped nanoparticles were $100 \mathrm{~nm}$ in size and spherical shaped nanoparticles were 5-10 $\mathrm{nm}$ in size. (Figure 3)

\section{X-ray Diffraction Analysis}

To confirm the reduction of graphene oxide further characterisation was done using XRD.

Two theta value was observed at around rGO $\left(2 \theta=27^{\circ}\right)$ corresponding to (002) plane. (Figure 4)

\section{FTIR Analysis}

The peak of 875.82 attributes to $\mathrm{C}-\mathrm{H}$ bending and ring puckering bending vibration. The peak of 1408.35 attributes to $\mathrm{O}-\mathrm{H}$ bending(in plane) vibration from hydroxyl groups. The absorp- tion range of 1600.91 attributes to $\mathrm{C}=\mathrm{C}$ (aromatic) stretching vibration which shows remaining sp 2 character. The peak of 2272 attributes to $\mathrm{C}=\mathrm{N}$ stretching vibration. The peak of 3028.34 attributes to $\mathrm{C}=\mathrm{C}-\mathrm{H}$ asymmetric stretching vibration. (Figure 5)

\section{Antimicrobial activity}

At all the concentrations of graphene oxide, there was zone of inhibition observed.

8-10 mm zone of inhibition was observed at the concentration of $25 \mu \mathrm{L}, 50 \mu \mathrm{L}$, and $150 \mu \mathrm{L}$. Antibiotic showed the maximum zone of inhibition of around $18 \mathrm{~mm}$ against tested microbes at all the concentrations. (Figure 6)

\section{Brine Shrimp Lethality assay}

Graphene oxide showed no cytotoxicity at concentration of 10 $\mu \mathrm{L}, 20 \mu \mathrm{L}$. As the concentration was increased the cytotoxic effects were evident. At the concentration of $50 \mu \mathrm{L}$ only 50 percent

Figure 1. Synthesis of Reduced Graphene Oxide Nanoparticles.

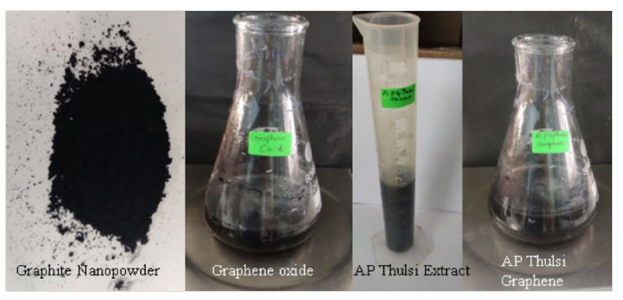

Figure 2. UV-Vis spectrophotometer Analysis.

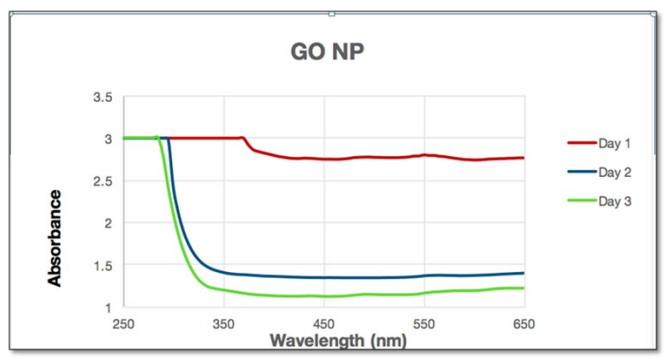

Figure 3. TEM image of rGO nanoparticles at $100 \mathrm{~nm}$ magnification.

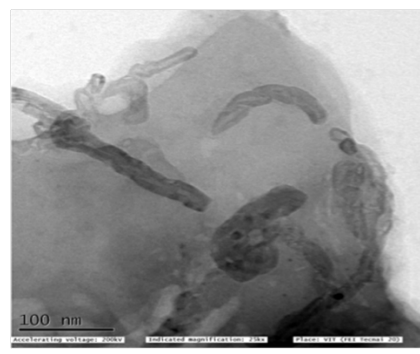

Figure 4. X-ray Diffraction assay.

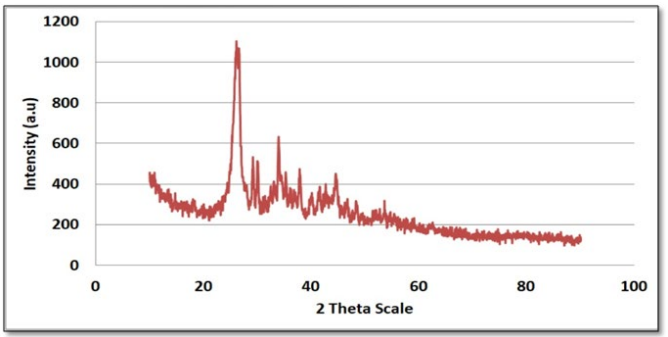


Figure 5. Fourier transform infrared spectroscopy.

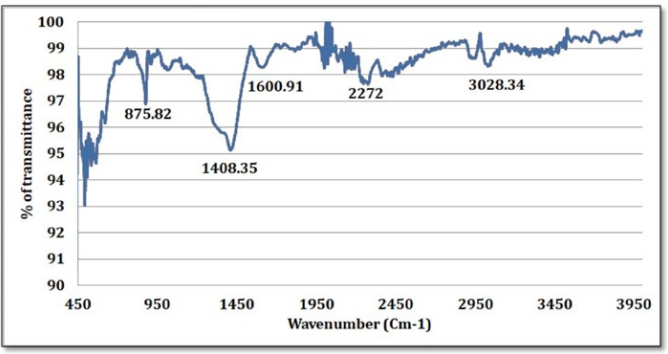

Figure 6. Antimicrobial activity of Reduced Graphene oxide nanoparticles.

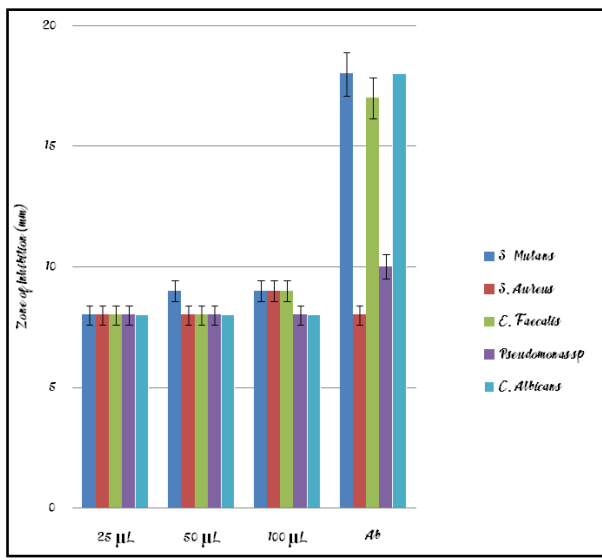

Figure 7. Brine shrimp lethality assay.

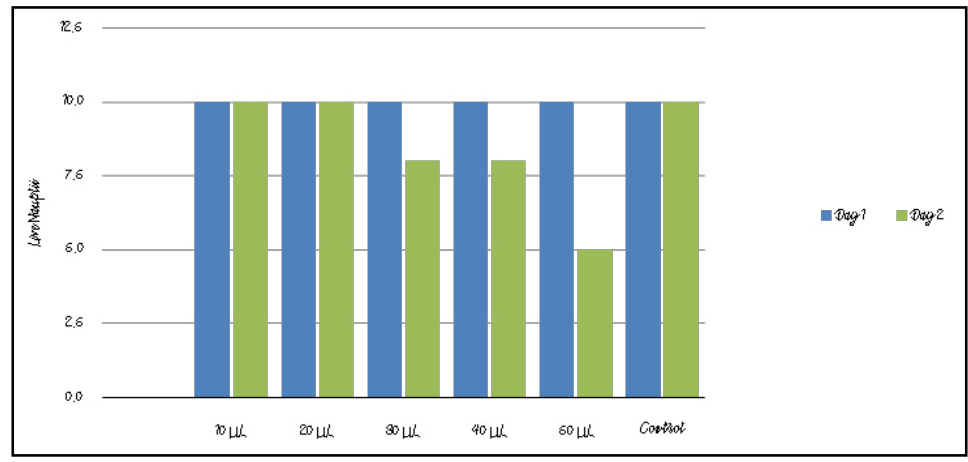

of nauplii were alive on day 2. (Figure 7)

The present study appear to be first of its kind as the combination of leaf extracts of Andrographis paniculata and Ocimum sanctum Linn to synthesise Graphene nanoparticles have not been reported previously in the literature.

The graphene nanoparticles were synthesised by an eco-friendly approach and characterisation was done using UV Vis Spectrophotometry, Transmission electron microscopy, FTIR Analysis andX-ray Diffraction assay to confirm the formation of reduced graphene oxide nanoparticles.

The UV Spectrophotometer analysis was done and the peak of $285 \mathrm{~nm}$ was observed after $72 \mathrm{hrs}$ which confirmed the synthesis of reduced graphene oxide nanoparticles. Our findings are consistent with the results of previously done studies. Atarod et al adopted green synthesis method to synthesise reduced graphene oxide and obtained peak at $265 \mathrm{~nm}$ [29]. Upadhyay et al synthesised reduced graphene oxide from grape seed extract and observed absorption peak at 270nm [30]. Transmission Electron microscopy confirmed the formation of rod shaped and spherical shaped nanoparticles.According to the results of FTIR, It was observed that there was no oxygenated functional group present. Zainuddin et al also observed similar functional groups during the synthesis reduced Graphene Oxide [31]. Two theta value for graphene oxide was observed at around $27^{\circ}$. The similar values are obtained in the previous studies $[32,33]$. The newly synthesised nanoparticles were able to exert some antimicrobial activity as evident from the results of our study.As stated by Jumaili et al antimicrobial activity is believed to be due to the capacity of graphene to physically damage microorganisms through different mechanisms; graphene nanostructure acts as a nano-knife and penetrates and cuts cell membrane of bacteria, it wraps cells induces mechanical stress, it has an ability to extract phospholipids from lipid membranes and it produces oxidative stress through ROS generation and by charge transfer phenomena. Molecular dynamic simulations have shown that thin graphene nanosheets can insert into both bacterial membranes creating a break and, once inserted, the Van Der Walls forces and the hydrophobic properties of graphene promote phospholipids extraction from the lipid layers of the bacterial membranes which causes irreversible damages [34].

Another way for graphene to exert antibacterial activity as reported by various researchers seems to be through the separa- 
tion of microorganisms from the microenvironment. Aggregated graphene sheets in suspension can isolate bacteria from the surrounding environment hinders nutrient consumption, reduces their ability to proliferate and favours their inactivation [35].

Li et al., showed that graphene has an ability to act as an electron pump by pulling out electrons from bacterial membranes and also induces ROS-independent oxidative stress that affects microorganisms [36].

Few contradictory studies have shown that graphene has no intrinsic bactericidal properties and it enhances bacterial growth in a colloidal suspension [37]. According to Das and Ruiz et al functionalization with antibacterial agents enhances the bactericidal activity of graphene-based nano-materials [37, 38]. In agreement with these studies, few collaborators confirmed that graphene alone has no antibacterial properties, but combination of graphene with iodine compounds have a potent antibacterial activity [39].

There are few major concerns related to graphene toxicity.The toxicity depends on surface functionalization, coating, size, the administration routes, dosage, time of exposure and type of material with which these are combined.We utilised Brine shrimp lethality assay to check the bioactivity of plant extracts used in our study.It is a rapid, inexpensive and simple tool which assesses the cytotoxicity $[40,41]$. The results of brine shrimp assay can give us an idea related to the cytotoxic effect of the plant extract used and can serve as a baseline.Graphene oxide nanoparticles were not toxic at lower concentration but as concentration was increased toxic effects were also noted.According to Ding et al low doses of GO had no cytotoxic effects on T lymphocytes, while a dose over $100 \mu \mathrm{g} / \mathrm{mL}$ caused oxidative stress related apoptosis after $24 \mathrm{~h}$ of incubation [42]. Pang and colleagues studied the ratio between biosafety and antibacterial activity of graphene and GO [43]. According to them both cytotoxicity and antibacterial effects are dose-dependent. Graphene oxide has a higher activity as compared to graphene, Graphene Oxide concentration in the range of $50-100 \mu \mathrm{g} / \mathrm{mL}$ seems to maintain the balance between minor cytotoxic effects and major antibacterial activity.

\section{Conclusion}

According to the results of the present study Graphene oxide showed good anti microbial properties and minimum or no cytotoxic effects at lower concentration. Future perspective of the present work is to combine Graphene oxide with some additives for improved antimicrobial properties. More precise assays can be utilised for assessment of cytotoxicity.

\section{References}

[1]. Novoselov KS, Geim AK, Morozov SV, Jiang D, Zhang Y, Dubonos SV, Grigorieva IV, Firsov AA. Electric field effect in atomically thin carbon films. Sci. 2004 Oct 22;306(5696):666-9.

[2]. Jastrzębska AM, Kurtycz P, Olszyna AR. Recent advances in graphene family materials toxicity investigations. J Nanopart Res. 2012 Dec;14(12):1320. Pubmed PMID: 23239936

[3]. Pham VT, Truong VK, Quinn MD, Notley SM, Guo Y, Baulin VA, et al. Graphene Induces Formation of Pores That Kill Spherical and Rod-Shaped Bacteria. ACS Nano. 2015 Aug 25;9(8):8458-67.PUBMED PMID: 26166486

[4]. Akhavan O, Ghaderi E, Esfandiar A. Wrapping bacteria by graphene na- nosheets for isolation from environment, reactivation by sonication, and inactivation by near-infrared irradiation. J Phys Chem B. 2011 May 19;115(19):6279-88.Pubmed PMID: 21513335.

[5]. Goenka S, Sant V, Sant S. Graphene-based nanomaterials for drug delivery and tissue engineering. J Control Release. 2014 Jan 10;173:75-88.

[6]. Mandal D, Bolander ME, Mukhopadhyay D, Sarkar G, Mukherjee P. The use of microorganisms for the formation of metal nanoparticles and their application. Appl Microbiol Biotechnol. 2006 Jan;69(5):485-92.

[7]. Kowshik M, Ashtaputre S, Kharrazi S, Vogel W, Urban J, Kulkarni SK, et al. Extracellular synthesis of silver nanoparticles by a silver-tolerant yeast strain MKY3. Nanotechnology. 2002 Dec 20;14(1):95.

[8]. Samadi N, Golkaran D, Eslamifar A, Jamalifar H, Fazeli MR, Mohseni FA. Intra/extracellular biosynthesis of silver nanoparticles by an autochthonous strain of Proteus mirabilis isolated from photographic waste. J Biomed Nanotechnol. 2009 Jun;5(3):247-53.Pubmed PMID: 20055006.

[9]. Philip D, Unni C, Aromal SA, Vidhu VK. Murraya Koenigii leaf-assisted rapid green synthesis of silver and gold nanoparticles. Spectrochim Acta A Mol Biomol Spectrosc. 2011 Feb;78(2):899-904.Pubmed PMID: 21215687.

[10]. Shukla VK, Yadav RS, Yadav P, Pandey AC. Green synthesis of nanosilver as a sensor for detection of hydrogen peroxide in water. J Hazard Mater. 2012 Apr 30;213-214:161-6.Pubmed PMID: 22365140.

[11]. Handa SS, Sharma A. Hepatoprotective activity of andrographolide from Andrographis paniculata against carbontetrachloride. Indian J Med Res. 1990 Aug;92:276-83.Pubmed PMID: 2228074.

[12]. Rana AC, Avadhoot Y. Hepatoprotective effects of Andrographis paniculata against carbon tetrachloride-induced liver damage. Arch. Pharm. Res. 1991 Mar;14(1):93-5.

[13]. Ramarao S, Sathyanarayanan U. CRA Grid - A preliminary development and calibration of a paper-based objectivization of caries risk assessment in undergraduate dental education. J Conserv Dent. 2019 Mar-Apr;22(2):185-190. Pubmed PMID: 31142991.

[14]. Poorni S, Srinivasan MR, Nivedhitha MS.Probiotic strains in caries prevention: A systematic review. J Conserv Dent.2019; 22: 123-128.

[15]. Manohar MP, Sharma S. A survey of the knowledge, attitude, and awareness about the principal choice of intracanal medicaments among the general dental practitioners and nonendodontic specialists. Indian J Dent Res. 2018 Nov-Dec;29(6):716-720.Pubmed PMID: 30588997.

[16]. Azeem RA, Sureshbabu NM. Clinical performance of direct versus indirect composite restorations in posterior teeth: A systematic review. J Conserv Dent. 2018 Jan-Feb;21(1):2-9.Pubmed PMID: 29628639.

[17]. Jenarthanan S, Subbarao C. Comparative evaluation of the efficacy of diclofenac sodium administered using different delivery routes in the management of endodontic pain: A randomized controlled clinical trial. J Conserv Dent. 2018 May-Jun;21(3):297-301.Pubmed PMID: 29899633.

[18]. Nandakumar M, Nasim I. Comparative evaluation of grape seed and cranberry extracts in preventing enamel erosion: An optical emission spectrometric analysis. J Conserv Dent. 2018 Sep-Oct;21(5):516-520.Pubmed PMID: 30294113.

[19]. Malli Sureshbabu N, Selvarasu K, V JK, Nandakumar M, Selvam D. Concentrated Growth Factors as an Ingenious Biomaterial in Regeneration of Bony Defects after Periapical Surgery: A Report of Two Cases. Case Rep Dent. 2019 Jan 22;2019:7046203.Pubmed PMID: 30805222.

[20]. Siddique R, Nivedhitha MS, Jacob B. Quantitative analysis for detection of toxic elements in various irrigants, their combination (precipitate), and para-chloroaniline: An inductively coupled plasma mass spectrometry study. J Conserv Dent. 2019 Jul-Aug;22(4):344-350.Pubmed PMID: 31802817.

[21]. Teja KV, Ramesh S, Priya V. Regulation of matrix metalloproteinase-3 gene expression in inflammation: A molecular study. J. Conserv. Dent. 2018 Nov;21(6):592-596.

[22]. Rajakeerthi R, Nivedhitha MS. Natural Product as the Storage medium for an avulsed tooth-A Systematic Review. Cumhur. Dent. J. 2019;22(2):24956.

[23]. Siddique R, Nivedhitha MS. Effectiveness of rotary and reciprocating systems on microbial reduction: A systematic review. J Conserv Dent. 2019 Mar-Apr;22(2):114-122.Pubmed PMID: 31142978.

[24]. Janani K, Sandhya R. A survey on skills for cone beam computed tomography interpretation among endodontists for endodontic treatment procedure. Indian J Dent Res. 2019 Nov-Dec;30(6):834-838.Pubmed PMID: 31939356.

[25]. Siddique R, Sureshbabu NM, Somasundaram J, Jacob B, Selvam D. Qualitative and quantitative analysis of precipitate formation following interaction of chlorhexidine with sodium hypochlorite, neem, and tulsi. J Conserv Dent. 2019 Jan-Feb;22(1):40-47.Pubmed PMID: 30820081.

[26]. Rajendran R, Kunjusankaran RN, Sandhya R, Anilkumar A, Santhosh R, Patil SR. Comparative evaluation of remineralizing potential of a paste containing bioactive glass and a topical cream containing casein phosphopeptide-amorphous calcium phosphate: An in vitro study. Pesqui. Bras. Odon- 
topediatria Clín. Integr. 2019;19:1-10.

[27]. Govindaraju L, Neelakantan P, Gutmann JL. Effect of root canal irrigating solutions on the compressive strength of tricalcium silicate cements. Clin Oral Investig. 2017 Mar;21(2):567-571.Pubmed PMID: 27469101.

[28]. Khandelwal A, Palanivelu A. Correlation between dental caries and salivary albumin in adult population in Chennai: An in vivo study. Braz. Dent. Sci. 2019 Apr 30;22(2):228-33.

[29]. Atarod M, Nasrollahzadeh M, Sajadi SM. Green synthesis of a Cu/reduced graphene oxide/Fe $3 \mathrm{O} 4$ nanocomposite using Euphorbia wallichii leaf extract and its application as a recyclable and heterogeneous catalyst for the reduction of 4-nitrophenol and rhodamine B. RSC Adv. 2015;5(111):9153243.

[30]. Upadhyay RK, Soin N, Bhattacharya G, Saha S, Barman A, Roy SS. Grape extract assisted green synthesis of reduced graphene oxide for water treatment application. Mater. Lett. 2015 Dec 1;160:355-8.

[31]. Zainuddin MF, Raikhan NN, Othman NH, Abdullah WF. Synthesis of reduced Graphene Oxide ( $\mathrm{rGO}$ ) using different treatments of Graphene Oxide (GO). IOP conf. ser., Mater. sci. eng. 2018 May 1;358(1): 012046.

[32]. Zeng X, McCarthy DT, Deletic A, Zhang X. Silver/reduced graphene oxide hydrogel as novel bactericidal filter for point-of-use water disinfection. Adv. Funct. Mater. $2015 \mathrm{Jul} ; 25(27): 4344-51$.

[33]. Habte AT, Ayele DW. Synthesis and characterization of reduced graphene oxide ( $\mathrm{rGO}$ ) started from graphene oxide (GO) using the tour method with different parameters. Adv. Mater. Sci. 2019 Aug 15;2019.

[34]. Al-Jumaili A, Alancherry S, Bazaka K, Jacob MV. Review on the antimicrobial properties of carbon nanostructures. Mater. 2017 Sep;10(9):1066.

[35]. Guazzo R, Gardin C, Bellin G, Sbricoli L, Ferroni L, Ludovichetti FS, et al. Graphene-based nanomaterials for tissue engineering in the dental field.
Nanomaterials. 2018 May;8(5):349.

[36]. Li J, Wang G, Zhu H, Zhang M, Zheng X, Di Z, et al. Antibacterial activity of large-area monolayer graphene film manipulated by charge transfer. Sci Rep. 2014 Mar 12;4(1):1-8.Pubmed PMID: 24619247.

[37]. Das MR, Sarma RK, Saikia R, Kale VS, Shelke MV, Sengupta P. Synthesis of silver nanoparticles in an aqueous suspension of graphene oxide sheets and its antimicrobial activity. Colloids Surf B Biointerfaces. 2011 Mar;83(1):1622.Pubmed PMID: 21109409.

[38]. Ruiz ON, Fernando KA, Wang B, Brown NA, Luo PG, McNamara ND, et al. Graphene oxide: a nonspecific enhancer of cellular growth. ACS Nano. 2011 Oct 25;5(10):8100-7.Pubmed PMID: 21932790.

[39]. Some S, Sohn JS, Kim J, Lee SH, Lee SC, Lee J, et al. Graphene-Iodine Nanocomposites: Highly Potent Bacterial Inhibitors that are Bio-compatible with Human Cells. Sci Rep. 2016 Feb 4;6:20015.Pubmed PMID: 26843066.

[40]. Krishnaraju AV, Rao TV, Sundararaju D, Vanisree M, Tsay HS, Subbaraju GV. Assessment of bioactivity of Indian medicinal plants using brine shrimp (Artemia salina) lethality assay. Int J Appl Sci Eng. 2005 Oct 1;3(2):125-34.

[41]. Osman N, Omar H.Brine Shrimp lethality assay (BSLA) of mixed micro algae extracts from Tilapia fish ponds.Jou Alga Bio Util.2019;10:8-13.

[42]. Ding Z, Zhang Z, Ma H, Chen Y. In vitro hemocompatibility and toxic mechanism of graphene oxide on human peripheral blood $T$ lymphocytes and serum albumin. ACS Appl Mater Interfaces. 2014 Nov 26;6(22):19797807.Pubmed PMID: 25371999.

[43]. Pang L, Dai C, Bi L, Guo Z, Fan J. Biosafety and Antibacterial Ability of Graphene and Graphene Oxide In Vitro and In Vivo. Nanoscale Res Lett. 2017 Oct 12;12(1):564.Pubmed PMID: 29027140. 